\title{
Addition of furfuryl alcohol and palm oil on physical and biological properties changes in UF- and citric acid-bonded particleboard
}

\author{
Zhou Huaxu, Lee Seng Hua, Paiman Bawon, Syeed SaifulAzry Al Edrus, Lee Ching Hao, Lum \\ Wei Chen
}

\begin{abstract}
This study investigates the physical and biological properties of urea formaldehyde (UF)- and citric acid-bonded particleboard. Furfuryl alcohol and palm oil were added into both $U F$ and citric acid in order to enhance the properties of the produced particleboard. Particleboard bonded with 4 different types of binder were tested for thickness swelling, water absorption, fungal and termite resistance. The results revealed poorer physical properties was recorded in the samples bonded with citric acid. However, the addition of palm oil and furfuryl alcohol had proven to be able to impart better physical properties to the resultant particleboards. In comparison to UF-bonded particleboard, better resistance against termites and fungus were also recorded in citric acid-bonded particleboard when furfuryl alcohol and palm oil were added. Therefore, with addition of suitable additives, citric acid is able served as a green binder with properties comparable to that of the urea formaldehyde resin.
\end{abstract}

Index Terms: Furfuryl alcohol, citric acid, palm oil, green binder, decay resistance

\section{INTRODUCTION}

Formaldehyde-based resin, particularly urea formaldehyde (UF) is the most prevalently used resin in manufacturing particularly owing to its high cost-effectiveness, high reactivity and results in superior binding strength [1]. However, they tend to release a substantial amount of formaldehyde, which is a toxic substance that are known as carcinogenic to human [1]. Also, the declination of non-renewable fossil resources is anticipated to restrict the usage of conventional synthetic resins in the near future. Therefore, the future trend of adhesive would be focused on natural and renewable non-fossil resources.

Revised Manuscript Received on July 05, 2019

Zhou Huaxu, Institute of Tropical Forestry and Forest Products, Universiti Putra Malaysia, 43400 UPM Serdang, Selangor, Malaysia

Lee Seng Hua, Institute of Tropical Forestry and Forest Products, Universiti Putra Malaysia, 43400 UPM Serdang, Selangor, Malaysia. Corresponding author.Email:lee_seng@upm.edu.my

Paiman Bawon, Faculty of Forestry, Universiti Putra Malaysia, 43400 UPM Serdang, Selangor, Malaysia

Syeed SaifulAzry Al Edrus, Institute of Tropical Forestry and Forest Products, Universiti Putra Malaysia, 43400 UPM Serdang, Selangor, Malaysia

Lee Ching Hao, Institute of Tropical Forestry and Forest Products, Universiti Putra Malaysia, 43400 UPM Serdang, Selangor, Malaysia

Lum Wei Chen, Institute for Infrastructure Engineering and Sustainable Management (IIESM), Universiti Teknologi MARA, 40450 Shah Alam, Selangor, Malaysia
Natural adhesive that can produce excellent bonding performance are favorable. On account to that, citric acid, also called 2-hydroxy-1, 2, 3-propanetricarboxylic acid, is potentially to be applied as binding agent to enhance the properties of agricultural residue particleboard. Citric acid is a green material widely used in foods, beverages, and pharmaceuticals. Citric acid, an organic polycarboxylic acid, is normally used as a crosslinking agent in wood properties enhancement as it contains three carboxyl groups that are able to react with the hydroxyl group of the wood polysaccharides. Apart from wood, citric acid has also been reported to be applied in improving the properties of plant fiber, paper, and starch [2]. Limited information was found in using citric acid as wood adhesive. Therefore, the feasibility of using citric acid as a natural adhesive for wood composite is further investigated in this study.

Previous unpublished study shows that the particleboard bonded with citric acid alone had inferior physical properties compared to that of the UF-bonded particleboard. Therefore, green materials such as furfuryl alcohol and palm oil can be added into the citric acid to impart better dimensional stability to the particleboard. Furfuryl alcohol is an environmentally friendly chemical because furfurylated wood and leachates from furfurylated wood shown no significant ecotoxicity. The alcohol groups of furfuryl alcohol are reported to have high potential to serve as polymerization and crosslinking agent [3]. Therefore, addition furfuryl alcohol could lower the hygroscopicity of the wood apart from impart superior mechanical properties to the wood. Besides, furfuryl alcohol is a totally green material where it can be produced industrially by hydrogenation of furfural. These furfurals could be easily obtained from waste biomass. Therefore, it is confirmed that furfuryl alcohol itself is a green chemical. Malaysia is one of the biggest producers of palm oil in the world. Vegetable oils including linseed and rapeseed oils, including palm oil are green materials that are safe to environment and has long been used in the wood protection treatment [4]. Apart from that, application of palm oil is able to substitute wax emulsion, non-green petroleum-based materials and to impart better dimensional

\section{MATERIALS AND METHODOLOGY}

\section{A. Materials}




\section{Addition of furfuryl alcohol and palm oil on physical and biological properties changes in UF- and citric acid-bonded particleboard}

The materials used in this study are rubberwood particles, urea formaldehyde resin, citric acid, furfuryl alcohol and palm oil. Rubberwood particles were obtained from Heveaboard Bhd, a particleboard manufacturer located in Gemas, Negeri Sembilan. The obtained particles were dried to $3 \%$ in a laboratory oven. Urea formaldehyde (UF) resin with $60-65 \%$ solid content was used as binder in this study. The UF resin was obtained from Aica Malaysia Sdn. Bhd located in Senawang. Citric acid in powder form was purchased from Evergreen Engineering \& Resources, Semenyih, Selangor. The citric acid was dissolved in distilled water to achieve $60 \%$ solid content and used as binder for the particleboard production. Furfuryl alcohol was purchased from Evergreen Engineering \& Resources, Semenyih, Selangor. The furfuryl alcohol was served as additives into the binders to impart better dimensional stability to the particleboard. Edible palm oil with a brand name of Vesawit was bought from a local groceries store. The palm oil was added into the binders to serve as water repellent to substitute wax emulsion.

\section{B. Preparation of Binding Agents}

Four different types of binders as shown in Table 1 were prepared for the manufacturing of particleboard. $10 \%$ urea formaldehyde (UF) resin based on oven dried weight of rubberwood particles was prepared for the production of UF-bonded particleboard (10\% UF). For another set of particleboard, $20 \%$ palm oil based on the resin solid content was added into the UF resin (10\% UF $+20 \%$ PO). On the other hand, citric acid powder was dissolved into distilled to attain $60 \%$ solid content. Then, $15 \%$ of citric acid based on oven dried weight of rubberwood particles was used as binders for citric acid-bonded particleboard (15\% CA). 20\% palm oil and $20 \%$ furfuryl alcohol were added into the citric acid $(15 \% \mathrm{CA}+20 \% \mathrm{PO}+20 \% \mathrm{FA})$ were used as binder to produce another set of particleboard.

TABLE 1: TYPES OF BINDER PREPARED FOR THE MANUFACTURING OF PARTICLEBOARD

\begin{tabular}{ll}
\hline Label & Binder \\
\hline $10 \%$ UF & $10 \%$ urea formaldehyde \\
$10 \%$ UF $+20 \%$ PO & $10 \%$ urea formaldehyde $+20 \%$ palm \\
& oil \\
$15 \%$ CA & $15 \%$ citric acid \\
$15 \%$ CA $+20 \%$ PO & $15 \%$ citric acid $+20 \%$ palm oil $+20 \%$ \\
$+20 \%$ FA & furfuryl alcohol \\
\hline
\end{tabular}

\section{Production of Experimental Particleboard}

Rubberwood (RW) particles were dried to $3 \%$ moisture content at $103 \pm 2{ }^{\circ} \mathrm{C}$ prior to particleboard fabrication. Particleboard with the measurements of $340 \times 340 \times 12 \mathrm{~mm}$ was produced with the target density of $650 \mathrm{~kg} / \mathrm{m}^{3}$. Three boards were produced for each treatment variable. Thus, a total of 12 boards were produced. Firstly, the rubberwood particles were placed in a blender where the resin was sprayed onto the particles during the blending process. After blending process, the particles were shaped into a mat form and was pre-pressed and then hot-pressed at $180^{\circ} \mathrm{C}$ for 4.5 minutes with 100 bar pressure. Properties evaluation for physical properties of the rubberwood particleboard was carried out after conditioning.

\section{Properties evaluation}

Thickness swelling and water absorption of the samples after $2 \mathrm{~h}$ - and $24 \mathrm{~h}$ - water soaking was determined. The decay resistance of the particleboard against white rot fungi, Pycnoporus sanguineus, were conducted in accordance to ASTM D2017- 05. On the other hand, termite resistance test was carried out based on ASTM D3345-08 where the samples were exposed to Subterranean termite, Coptotermus curvignathus.

\section{RESULTS AND DISCUSSION}

\section{A. Physical properties}

Table 2 displays the thickness swelling (TS) and water absorption (WA) of the particleboard samples after 2 hours and 24 hours of immersion in water. Significant differences were observed among the four types of samples bonded with different types of binding agent. The control particleboard made from $10 \%$ UF recorded $19.33 \%$ and $33.34 \%$ for $\mathrm{TS}_{2 \mathrm{~h}}$ and $\mathrm{TS}_{24 \mathrm{~h}}$, respectively. Meanwhile, particleboard made from $10 \%$ UF resin added with $20 \%$ of palm oil $(10 \%$ UF $+20 \%$ PO) showed $\mathrm{TS}_{2 \mathrm{~h}}$ of $12.47 \%$ and $\mathrm{TS}_{24 \mathrm{~h}}$ of $29.36 \%$. This indicates that the addition of palm oil has improved the thickness swelling of the particleboard significantly. Yingprasert et al. [5] reports a reduction in both $\mathrm{TS}_{2 \mathrm{~h}}$ and $\mathrm{TS}_{24 \mathrm{~h}}$ for the rubberwood particleboard added with 0.6 to $3.0 \%$ cinnamon oil and clove oil. On the other hand, particleboard made with $15 \%$ citric acid (C15) displayed an extremely high $\mathrm{TS}_{2 \mathrm{~h}}$ and $\mathrm{TS}_{24 \mathrm{~h}}$, which were $76.01 \%$ and $79.66 \%$, respectively. The values were 2 to 3 -folds higher than the particleboard type OA20 and control.

TABLE 2; THICKNESS SWELLING (TS) AND WATER ABSORPTION (WA) OF THE SAMPLES AFTER 2 HOURS AND 24 HOURS IMMERSION IN WATER

\begin{tabular}{|c|c|c|c|c|c|}
\hline Sample & & $\mathrm{TS}_{2 \mathrm{~h}}(\%)$ & $\mathrm{TS}_{24 \mathrm{~h}}(\%)$ & $\begin{array}{l}W_{2 h} \\
(\%)\end{array}$ & $\begin{array}{l}\mathrm{WA}_{24 \mathrm{~h}} \\
(\%)\end{array}$ \\
\hline $10 \% \mathrm{UF}$ & & $\begin{array}{l}19.33 \\
2.30^{\mathrm{b}}\end{array}$ & $\begin{array}{l}33.34 \quad \pm \\
2.08^{\mathrm{b}}\end{array}$ & $\begin{array}{l}90.55 \\
7.85^{\mathrm{c}}\end{array}$ & $\begin{array}{l}116.55 \pm \\
8.14^{\mathrm{b}}\end{array}$ \\
\hline $\begin{array}{l}10 \% \text { UF } \\
20 \% \text { PO }\end{array}$ & & $\begin{array}{l}12.47 \\
3.33^{\mathrm{a}}\end{array}$ & $\begin{array}{l}29.36 \\
3.13^{\mathrm{a}}\end{array}$ & $\begin{array}{l}77.81 \quad \pm \\
8.35^{\mathrm{a}}\end{array}$ & $\begin{array}{l}102.57 \pm \\
7.75^{\mathrm{a}}\end{array}$ \\
\hline $15 \% \mathrm{CA}$ & & $\begin{array}{l}76.01 \pm \\
6.23^{\mathrm{c}}\end{array}$ & $\begin{array}{l}79.66 \\
9.35^{\mathrm{c}}\end{array}$ & $\begin{array}{c}145.01 \\
\pm 11.61^{\mathrm{d}}\end{array}$ & $\begin{array}{l}113.59 \pm \\
55.48^{\mathrm{b}}\end{array}$ \\
\hline $\begin{array}{ll}15 \% & \text { CA } \\
20 \% & \text { PO }\end{array}$ & $\begin{array}{l}+ \\
+\end{array}$ & $\begin{array}{l}19.01 \pm \\
2.74^{\mathrm{b}}\end{array}$ & $\begin{array}{l}36.24 \quad \pm \\
2.56^{\mathrm{b}}\end{array}$ & $\begin{array}{l}83.99 \quad \pm \\
7.13^{b}\end{array}$ & $\begin{array}{l}110.87 \pm \\
9.22^{\mathrm{b}}\end{array}$ \\
\hline
\end{tabular}
*number after " \pm " are standard deviation;
** The values within the same column followed by the same letter is not significant different at
$\mathrm{p} \leq 0.05$

As for WA, control particleboard made from $10 \%$ 
UF recorded a $\mathrm{WA}_{2 \mathrm{~h}}$ of $90.55 \%$ and $\mathrm{WA}_{24 \mathrm{~h}}$ of $116.5 \%$, respectively. Particleboard made with $15 \% \mathrm{CA}$ had the highest WA values. Meanwhile, samples made with $10 \%$ UF $+20 \%$ PO had the lowest WA values, indicating that addition of palm oil into UF resin significantly improved the WA of the samples. Umemura et al. [2] report the feasible of citric acid as binding agent for particleboard. However, application of citric acid alone might not be enough to impart good physical properties to the particleboard. Addition of crosslinking agent such as sucrose in the adhesion system is needed. In this study, furfuryl alcohol and palm oil was added. As a result, both $\mathrm{TS}_{2 \mathrm{~h}}$ and $\mathrm{TS}_{24 \mathrm{~h}}$ of the particleboard made with $15 \% \mathrm{CA}+20 \% \mathrm{PO}+20 \% \mathrm{FA}$ was greatly improved. The $\mathrm{TS}_{2 \mathrm{~h}}$ for the particleboard was $19.01 \%$ while the $\mathrm{TS}_{24 \mathrm{~h}}$ was $36.24 \%$. Furfuryl alcohol has been known to be able to enhance the dimensional stability of the wood. FA has blocked the wood cavity and the formation of cross linkage might be the probable reason that resulted in significant improvement in thickness swelling of the manufactured particleboard [6]. Furthermore, the addition of $20 \%$ palm oil has exerted a synergetic effect in improving the thickness swelling of the particleboard.

\section{B. Fungal and termite resistance}

The visual appearance of particleboards bonded with different binding agents after exposure to Pycnoporus sanguineus are illustrated in Figure 1. It can be seen that the control particleboard (10\% UF) has been covered by the mycelia of Pycnoporus sanguineus, indicated that it is prone to the fungal attack. However, for particleboards made with $10 \% \mathrm{UF}+20 \% \mathrm{PO}, 15 \% \mathrm{CA}$ and $15 \% \mathrm{CA}+20 \% \mathrm{PO}+20 \%$ $\mathrm{FA}$, the mycelia coverage is significantly lesser than that of the control board.

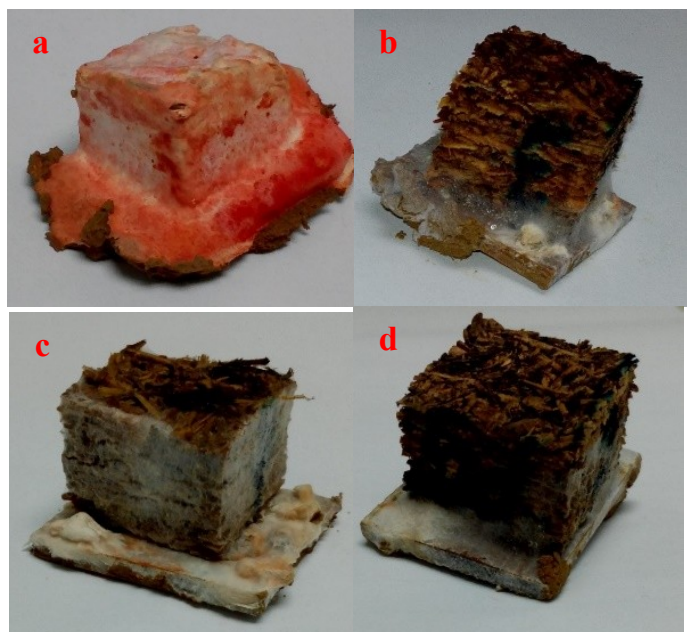

Fig. 1: Visual appearance of particleboards bonded with different binding agents after exposure to Pycnoporus sanguineus: (a) 10\% UF; (b) 10\% UF + 20\% PO; (c) 15\% CA and (d) $15 \% \mathrm{CA}+20 \% \mathrm{PO}+20 \% \mathrm{FA}$

Figure 2 illustrates the visual appearance of the particleboards bonded with different binding agents after exposure to Coptotermus curvignathus. It can be observed that $10 \%$ UF (a) and 15\% CA (c) samples were severely attacked while $10 \% \mathrm{UF}+20 \%$ PO (b) and $15 \% \mathrm{CA}+20 \%$ $\mathrm{PO}+20 \%$ FA (d) displayed moderate attack where most of the samples stayed intact except some nibbles on the surfaces.

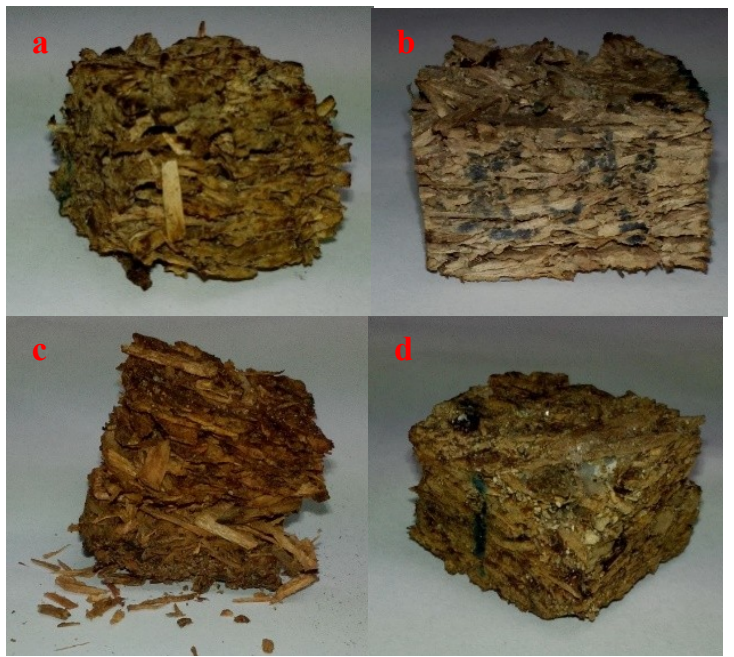

Fig. 2: Visual appearance of particleboards bonded with different binding agents after exposure to Coptotermus curvignathus: (a) 10\% UF; (b) 10\% UF + 20\% PO; (c) $15 \%$ $\mathrm{CA}$ and (d) $15 \% \mathrm{CA}+20 \% \mathrm{PO}+20 \% \mathrm{FA}$

Table 3 lists the weight loss (WL) of samples after exposed to Pycnoporus sanguineus and Coptotermus curvignathus. The weight losses of $61.45,5.85,7.94$ and $5.10 \%$ were observed in the samples treated as in $10 \% \mathrm{UF}, 10 \% \mathrm{UF}+20 \% \mathrm{PO}, 15 \%$ $\mathrm{CA}$ and $15 \% \mathrm{CA}+20 \% \mathrm{PO}+20 \% \mathrm{FA}$, respectively. The results revealed that citric acid, furfuryl alcohol and palm oil has enhanced the resistance of particleboard against fungi. Venås [7] proposed that the increment in decay resistance of furfurylated wood was possibly due to the reduction in void volume through bulking. According to Yingprasert et al. [5], a reduction in weight loss for rubberwood particleboards treated with cinnamon and clove oils was testified after exposed to Trametes sp. It can be assumed that palm oil portrayed the same capability as in cinnamon and clove oils in fungal activities inhibition.

Table 3 Weight loss (WL) of samples after exposed to Pycnoporus sanguineus and Coptotermus curvignathus

\begin{tabular}{lll}
\hline Sample & $\begin{array}{c}\text { WL (\%) caused by } \\
\text { fungus }\end{array}$ & $\begin{array}{l}\text { WL (\%) caused } \\
\text { by termites }\end{array}$ \\
\hline $10 \%$ UF & $61.45 \pm 6.86^{\mathrm{c}}$ & $55.68 \pm 13.26^{\mathrm{d}}$ \\
\hline $10 \%$ UF + & $5.85 \pm 0.95^{\mathrm{a}}$ & $28.22 \pm 10.42^{\mathrm{a}}$ \\
$20 \% \mathrm{PO}$ & & \\
\hline $15 \% \mathrm{CA}$ & $7.94 \pm 0.57^{\mathrm{b}}$ & $40.31 \pm 7.74^{\mathrm{c}}$ \\
\hline $15 \%$ CA + & $5.10 \pm 0.46^{\mathrm{a}}$ & $37.95 \pm 13.68^{\mathrm{b}}$ \\
$20 \%$ PO + & & \\
$20 \% \mathrm{FA}$ & &
\end{tabular}

\footnotetext{
*number after " \pm " are standard deviation;
$* *$ The values within the same column followed by the same letter is not significant different at $\mathrm{p} \leq 0.05$
} 
As for the weight loss of board samples after 4-week exposure to the Coptotermus curvignathus. The highest weight loss $(55.68 \%)$ was found in $10 \%$ UF sample, indicating a lack of resistance to attack towards Coptotermus curvignathus. Weight loss value in particleboard made with $15 \%$ CA was $15.37 \%$ lesser than board made with $10 \%$ UF. Indrayani et al. [8] attributed the improvement to the high acidic environment that devastate the termites. The particleboard made with $10 \%$ UF $+20 \%$ PO demonstrated the lowest in weight loss of $28.22 \%$. For the particleboard made with $15 \% \mathrm{CA}+20 \% \mathrm{PO}+20 \% \mathrm{FA}$, it gave a weight loss of $37.95 \%$ after exposure to subterranean termite. The addition of furfuryl alcohol in the binder mixture is proven in the earlier work by Ozaki et al. [9] who reported that furfuryl alcohol-boron complexes could provide biological resistance for wood.

\section{CONCLUSIONS}

In general, poorer physical properties was observed in the samples bonded with citric acid. However, the addition of palm oil and furfuryl alcohol had proven to be able to impart better physical properties to the resultant particleboards. Accordingly, an affirmative conclusion could be made that the mixture of $15 \% \mathrm{CA}+20 \% \mathrm{PO}+20 \%$ FA could substitute UF resin. The resulted particleboard exhibited better resistance against fungus and termites compared to that of the particleboard bonded with $10 \%$ UF. In addition, it showed no significant different in thickness swelling and water absorption in comparison to the UF-bonded particleboard.

\section{ACKNOWLEDGMENT}

This project was supported by Higher Institutions' Centre of Excellence (HICoE) and Geran Universiti Putra Malaysia (GP) GP/2017/9575500.

\section{REFERENCES}

1. A.M. Ferreira, J. Pereira, M. Almeida, J. Ferra, N. Paiva, J. Martins, F.D. Magalhães, and L.H. Carvalho, "Biosourced binder for wood particleboards based on spent sulfite liquor and wheat flour," Polymers, vol.10, 2018, 1070.

2. K. Umemura, O. Sugihara, and S. Kawai, "Investigation of a new natural adhesive composed of citric acid and sucrose for particleboard," Journal of Wood Science, vol.59(3), 2013, pp. 203-208.

3. S. Lande, M. Westin, and M. Schneider, "Properties of furfurylated wood," Scandinavian Journal of Forest Research, vol.19, 2004, pp. 22-30.

4. S.H. Lee, Z. Ashaari, W.C. Lum, A.H. Juliana, A.F. Ang. L.P. Tan, K.L. Chin, and Paridah, M.T, "Thermal treatment of wood using vegetable oils: A review," Construction and Building Materials, vol.181, 2018, pp. 408-419.

5. 5. W. Yingprasert, N. Matan, P. Chaowana, and N. Matan, "Fungal resistance and physico-mechanical properties of cinnamon oil- and clove oil-treated rubberwood particleboards," Journal of Tropical Forest Science, vol. 27, 2015, pp. 69-79.

6. W. Li, H. Wang, D. Ren, Y.S. Yu, Y. Yu, "Wood modification with furfuryl alcohol catalysed by a new composite acidic catalyst," Wood Science and Technology, vol. 49, 2015, pp. 845-856.
7. T.M. Venås, A study of mechanisms related to the fungal decay protection rendered by wood furfurylation. University of Copenhagen, Copenhagen, 2008.

8. Y. Indrayani, D. Setyawati, S.S. Munawar, K. Umemura, and T. Yoshimura, "Evaluation of termite resistance of medium density fiberboard (MDF) manufacture from agricultural fiber bonded with citric acid," Procedia Environmental Sciences, vol.28, 2015, pp. 778-782.

9. S.K. Ozaki, M.K. Yalinkilic, Y. Imamura, and M.F. Souza, Effect of combined boron compounds and furfuryl alcohol treatment on termite and decay resistance in wood. In: Imamura Y (ed) High-performance utilization of wood for outdoor uses. Report on research project. Grant-in-aid for scientific research, Kyoto, 2001, pp.97-103.

\section{AUTHORS PROFILE}

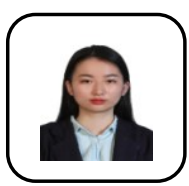

Zhou Huaxu is a $\mathrm{PhD}$ student from Institute of Tropical Forestry and Forest Products, Universiti Putra Malaysia. She is currently in her third semester.

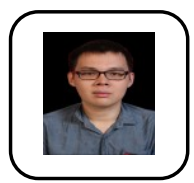

Lee Seng Hua is a research fellow from Institute of Tropical Forestry and Forest Products, Universiti Putra Malaysia, majoring in wood science and technology.



Paiman Bawon is a lecturer from Faculty of Forestry, Universiti Putra, majoring in wood science.

Syeed SaifulAzry Al Edrus is a research officer from $\Rightarrow \begin{aligned} & \text { Institute of Tropical Forestry and Forest Products, } \\ & \text { Universiti Putra Malaysia, majoring in nanocomposite }\end{aligned}$ science.

Lee Ching Hao is a post-doctoral researcher from Institute of Tropical Forestry and Forest Products, Universiti Putra Malaysia, majoring in biocomposite science.

Lum Wei Chen is a post-doctoral researcher from Institute for Infrastructure Engineering and Sustainable Management (IIESM), Universiti Teknologi MARA, majoring in wood science and technology. 